\title{
37. DATA REPORT: CARBON AND CARBONATE CONTENTS OF THE CENOMANIAN-TURONIAN SEDIMENTS FROM HOLE 869B (LEG 143): COMPARISON WITH OTHER DEEP BASINS FROM CENTRAL AND NORTHWESTERN PACIFIC OCEAN ${ }^{1}$
}

\author{
François Baudin ${ }^{2}$
}

\begin{abstract}
Dark gray claystone and siltstone, correlated with a positive gamma-ray peak, were recovered around the Cenomanian/ Turonian boundary at Hole $869 \mathrm{~B}$. Organic carbon and calcium carbonate contents were measured on 22 samples chosen in the different lithologies, especially in dark-colored facies, from Cores 143-869B-37R to -34R. The organic carbon content is everywhere less than $0.2 \%$, whereas calcium carbonate content ranges from $0 \%$ to $22 \%$. The organic matter appears intensely reworked or strongly oxidized, and is related to type IV kerogen.

Such low organic carbon contents seem common in the coeval sediments from basinal environments investigated by other DSDP and ODPdrilling in central and northwestern Pacific Ocean. Only a thin redeposited carbonaceous level from Site 585 (East Mariana Basin) represents the deepest evidence of the Cenomanian-Turonian Oceanic Anoxic Event in the Pacific Ocean.

A necessary condition of the oxygen-minimum-zone model proposed to explain the Cenomanian-Turonian Oceanic Anoxic Event is that basinal waters were oxygenated. These conditions are now further demonstrated in the deep basin flanking of the Pikinni-Wodejebato Ridge in the Marshall Islands.
\end{abstract}

\section{INTRODUCTION}

Site 869 , drilled during Leg 143 , is located in the northwestern Pacific Ocean, $83 \mathrm{~km}$ southwest to the Pikinni-Wodejebato atoll-guyot pair (Fig. 1). At this deep site (water depth of $4842 \mathrm{~m}$ ), a Cenomanianto-Campanian volcaniclastic series interlayered with nannofossil and radiolarian claystones was cored (Shipboard Scientific Party, 1993).

Dark gray claystone and siltstone, correlated with a positive gammaray peak, were recovered in Hole 869B, around the Cenomanian/ Turonian boundary. To search for organic-carbon-rich layers at this stratigraphic interval, closely spaced samples were taken in the 29-mthick interval from Cores 143-869B-37R to -34R.

Such horizons were described as organic-carbon-rich at a number of Pacific sites, including the nearby deep Mariana Basin (Moberly, Schlanger, et al., 1986). The presence of these organic-carbon-rich layers at, or very close to, the Cenomanian/Turonian boundary, their content of marine organic matter, and their lack of any other organicrich sediments above or below led to the interpretation that these layers are the indication, in the deep basins, of the Cenomanian-Turonian Oceanic Anoxic Event (Schlanger and Jenkyns, 1976; Schlanger et al., 1987)

\section{DESCRIPTION OF THE CENOMANIAN-TURONIAN DEPOSITS AT HOLE 869B}

At the base of Hole 869B, a thick upper Cenomanian section of basaltic breccia, associated with dark-colored coarse-grained volcaniclastic sandstone, was recovered. The sediments cored between Cores 143-869B-37R and -34R mark a change in the pattern of sedimentation. These consist mainly of gray to greenish-gray zeolitic fine-grained volcaniclastic sandstone, interbedded with gray to black, slightly calcareous siltstone. The volcaniclastic sandstone layers are generally sharp-based, parallel-laminated, and locally graded. Some layers contain radiolarians, large foraminifers, echinoids, ooids, and bivalve or gastropod debris (Shipboard Scientific Party, 1993). The

${ }^{1}$ Winterer. E.L., Sager, W.W., Firth, J.V., and Sinton, J.M. (Eds.), 1995. Proc. ODP, Sci. Results, 143: College Station, TX (Ocean Drilling Program).

${ }^{2}$ CNRS-URA 1761 et Département de Géologie Sédimentaire, Université Pierre et Marie Curie, 4 place Jussieu, 75252 Paris Cedex 05, France.

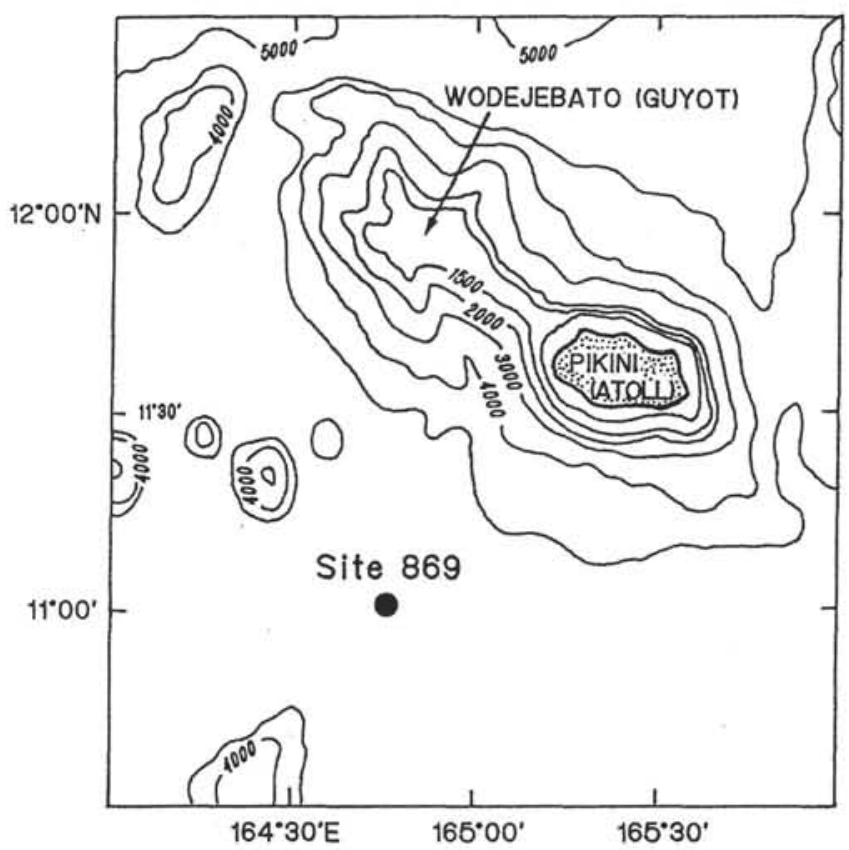

Figure 1. Map showing the location of Site 869 and the Pikinni-Wodejebato atoll-guyot pair.

gray volcaniclastic siltstones contain nannofossils, planktonic foraminifers, and radiolarians as the background sediment. Siltstone is predominant in Core 143-869B-36R and passes upward to laminated calcareous claystone and siltstone beds rich in radiolarians (Fig. 2 ). The fine lamination and the relative abundance of couplets of thin, fine-grained sandstone and siltstone suggest an outer-fan turbidite deposit. Chert and silicified claystone, as subordinate lithologies, occur within this interval. An interesting feature of the poorly recovered Core 143-869B-37R is the presence of dark gray to olive black calcareous siltstone in the core-catcher sample. The age of the studied interval, on the basis of nannofossils, is probably late Cenomanian up to Sample 143-869B-36R-1, 89 cm, whereas sedi- 


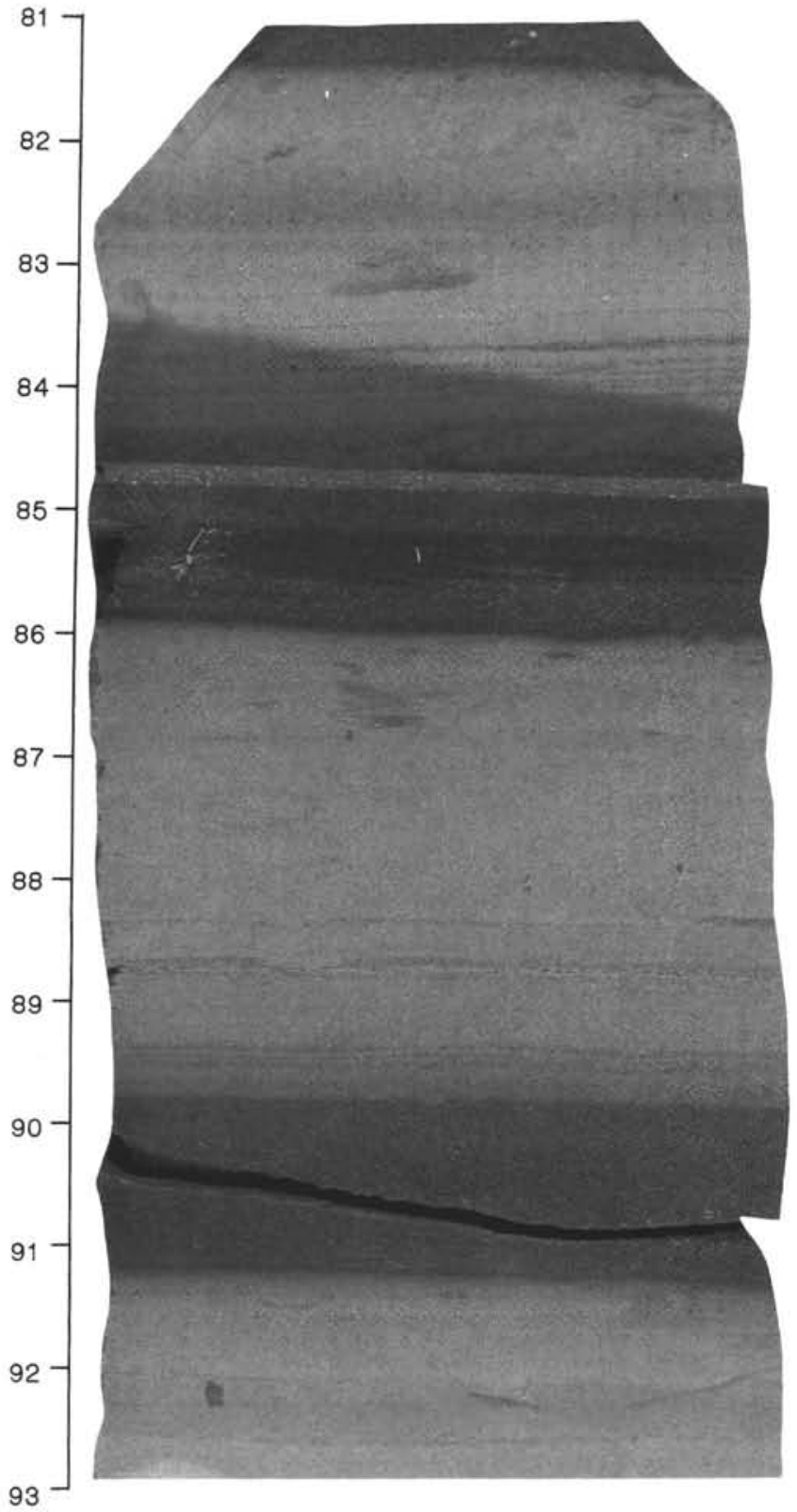

Figure 2. Photograph of alternating dark-colored sandstone and light-colored siltstone (interval 143-869B-34R-1, 81-93 cm), showing sharp contacts and lamination of a radiolarian-rich level.

ments from Sample 143-869B-35R-1, $84 \mathrm{~cm}$, are Turonian (Shipboard Scientific Party, 1993; Mutterlose and Bralower, this volume). The Cenomanian/Turonian boundary thus appears to lie in lithologic Subunit IIIC at about 469 mbsf.

\section{SAMPLING AND METHODS}

Twenty-two samples were selected in the different lithologies described above, especially in dark-colored facies from Cores 143869B-37R to -34R. This selection was supplemented by 11 samples from the same interval, which had been analyzed aboard the JOIDES Resolution. The first group of 22 samples was analyzed onshore for total organic content using both Rock-Eval and Leco analyzers. A crushed sample of $0.1 \mathrm{~g}$ was pyrolyzed using the Rock-Eval analyzer
(Espitalié et al., 1985a, 1985b, 1986). This technique supplies the free and potential hydrocarbons, as well as total organic carbon (TOC) content, and the $T_{\max }$ parameter, which is a thermal maturation index.

About $0.5 \mathrm{~g}$ of crushed sample was acidified with dilute hydrochloric acid and titrated for carbonate content measurement. The calcium carbonate percentage was calculated as follows: \% acidsoluble carbon $\times 8.33=\% \mathrm{CaCO}_{3}$, assuming that all carbonates are calcite. The sample was then dried and analyzed for acid-insoluble carbon, which was assumed to be "organic" carbon, using the Leco analyzer. All results are given in weight percent (Table 1). Precision for the analyses is as follows: organic carbon $\pm 5 \%$ using Rock-Eval and $\pm 2 \%$ for Leco; calcium carbonate content $\pm 1 \%$.

\section{RESULTS}

All samples show low calcium carbonate contents, which range from $0 \%$ to $22 \%$ (Fig. 3). A number of couplets of alternating lightand dark-colored sandstone and siltstone were specifically sampled to examine the difference in contents of $\mathrm{CaCO}_{3}$ among different colored lithologies. In general, lower concentrations were found in the black and greenish sandstone, while higher values were found in the lighter-colored (dark gray) siltstone and claystone. In these latter, calcareous nannofossils constitute the main component of the carbonate (Shipboard Scientific Party, 1993).

The organic carbon values of all samples are significantly low. The most organic-enriched sample (143-869B-36R-2, 19-21 cm) contains only $0.2 \%$ total organic carbon (TOC), according to Leco measurement (Table 1). The organic carbon percentages from Rock-Eval appear everywhere lower in comparison with Leco. This difference must be attributed either to the mineral matrix effect during RockEval pyrolysis of an organic-poor sample (Espitalié et al., 1985a, $1985 \mathrm{~b}$ ) or to the fact that the Leco apparatus reaches a higher temperature than does the Rock-Eval and, hence, gives a more complete burning of the organic matter. The interpretable $\mathrm{S}_{2}$ peaks, furnished by Rock-Eval, are extremely flat, and organic matter appears to consist mainly of so-called "dead carbon" or "type IV" kerogen (Tissot, 1984). Type IV kerogen corresponds to organic matter that has been intensely reworked or strongly oxidized.

The values of TOC for all samples analyzed (both shipboard and shore-based analyses) have been plotted vs. the $\mathrm{CaCO}_{3}$ content in Figure 4. It is obvious from this figure that there is a strong increase in organic carbon content of the shipboard-analyzed samples, compared to that in shore-based-analyzed samples. It is not clear if this difference is geochemically significant or if it is, at least partly, the result of a systematic error in the shipboard analytical procedure that may have overestimated the organic carbon.

\section{OVERVIEW OF ORGANIC CONTENT FROM CENOMANIAN-TURONIAN DEEP-WATER DEPOSITS IN CENTRAL AND NORTHWESTERN PACIFIC BASINS}

Several deep basins, with paleodepths ranging from 3500 to 5500 $\mathrm{m}$, were investigated by DSDP and ODP drilling in the central and northwestern Pacific Ocean. Some of these, which gave a good core recovery (Fig. 5), include Cenomanian to Turonian strata that are occasionally rich in organic carbon.

\section{North of Clarion Fracture Zone}

Site 164 was drilled to the north of the extension of the Clarion Fracture Zone between Line Islands and Hawaii. From Cores 17-16417 to 17-164-19, zeolitic brown clay, porcellanite, and claystone of Cenomanian-Turonian age were described (Winterer, Ewing, et al., 1973). To the best of my knowledge, no organic carbon measurements 


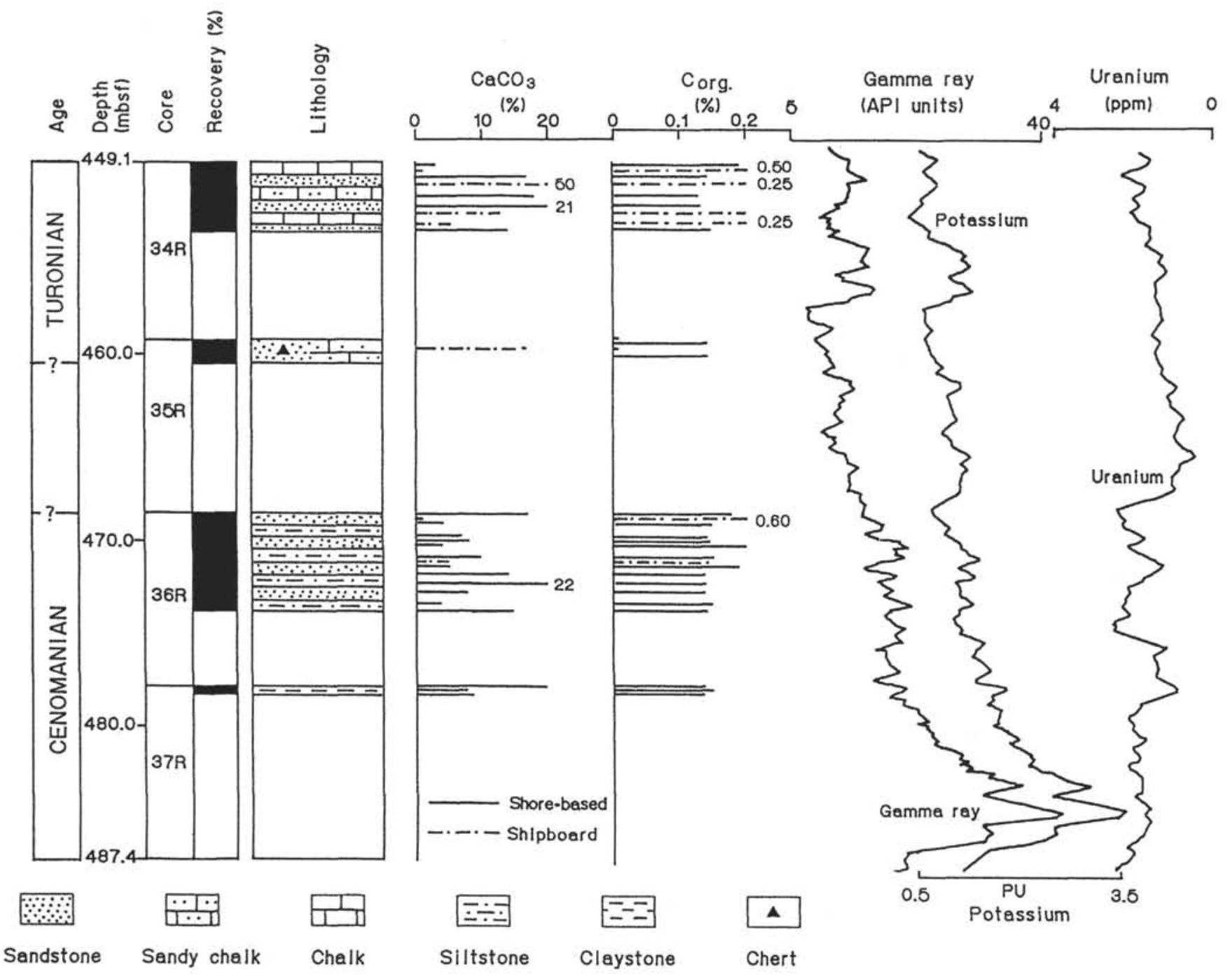

Figure 3. Lithology, carbonate and carbon contents, and selected shipboard well-logging records of the upper Cenomanian to middle-upper Turonian sediments from Cores 143-869B-34R to -37R. Graphic symbols of the column are schematic and do not represent the true thickness of the alternating lithologies.

Table 1. Carbonate and carbon data of the upper Cenomanian to middle-upper Turonian sediments from Hole 869B.

\begin{tabular}{|c|c|c|c|c|c|c|c|}
\hline $\begin{array}{l}\text { Core, section, } \\
\text { interval }(\mathrm{cm})\end{array}$ & $\begin{array}{l}\text { Depth } \\
\text { (mbsf) }\end{array}$ & Lithology & $\begin{array}{c}\mathrm{CaCO}_{3} \\
(\%)\end{array}$ & $\begin{array}{c}\mathrm{C}_{\text {org }} \\
\text { Rock-Eval }\end{array}$ & $\begin{array}{l}C_{\text {org }} \\
\text { Leco }\end{array}$ & $T_{\max }$ & $\mathrm{S}_{2}$ \\
\hline $34 \mathrm{R}-1,42-44$ & 449.52 & Dark gray clayey chalk & 3 & 0.01 & 0.19 & 581 & 0.04 \\
\hline $34 \mathrm{R}-1,84-86$ & 449.94 & Dark gray clayey chalk & 17 & 0.03 & 0.14 & 583 & \\
\hline $34 \mathrm{R}-2,34-35$ & 450.94 & Dark gray calcareous claystone & 18 & 0.01 & 0.13 & 583 & \\
\hline $34 \mathrm{R}-2,88-92$ & 451.48 & Dark gray calcareous claystone & 21 & 0.02 & 0.13 & 583 & \\
\hline $34 \mathrm{R}-\mathrm{CC}, 10-12$ & 452.60 & Dark gray calcareous claystone & 14 & 0.04 & 0.15 & 490 & 0.10 \\
\hline $35 R-1,36-38$ & 459.16 & Greenish gray sandy limestone & 0 & 0.03 & 0.14 & 551 & 0.34 \\
\hline $35 \mathrm{R}-1,77-79$ & 459.57 & Light gray sandy limestone & 0 & 0.01 & 0.14 & 550 & 0.17 \\
\hline $36 \mathrm{R}-1,2-4$ & 468.42 & Dark volcanicalstic siltstone & 17 & 0.08 & 0.18 & 549 & \\
\hline $36 \mathrm{R}-1,52-54$ & 468.92 & Black laminated sandy claystone & 4 & 0.03 & 0.15 & 548 & 0.19 \\
\hline $36 \mathrm{R}-1,128-130$ & 469.68 & Black laminated sandy claystone & 7 & 0.01 & 0.14 & 540 & \\
\hline $36 \mathrm{R}-1,145-150$ & 469.85 & Black laminated sandy claystone & 8 & 0.01 & 0.14 & 540 & \\
\hline $36 \mathrm{R}-2,19-21$ & 470.09 & Black laminated sandy claystone & 4 & 0.01 & 0.20 & 554 & 0.15 \\
\hline $36 \mathrm{R}-2,109-110$ & 470.99 & Dark laminated siltsone & 10 & 0.01 & 0.15 & 469 & 0.04 \\
\hline $36 \mathrm{R}-3,24-26$ & 471.64 & Black laminated sandy claystone & 5 & & 0.19 & & \\
\hline $36 \mathrm{R}-3,66-67$ & 472.06 & Dark laminated siltsone & 14 & & 0.14 & & \\
\hline $36 \mathrm{R}-3,114-115$ & 472.54 & Black laminated sandy claystone & 22 & 0.01 & 0.14 & 515 & \\
\hline $36 \mathrm{R}-4,8-9$ & 472.98 & Black laminated sandy claystone & 8 & & 0.14 & & \\
\hline $36 R-4,71-72$ & 473.61 & Black laminated sandy claystone & 4 & & 0.15 & & \\
\hline $36 \mathrm{R}-\mathrm{CC}, 3-4$ & 473.71 & Black laminated sandy claystone & 15 & & 0.14 & & \\
\hline 37R-CC, $1-2$ & 478.11 & Black sandy claystone & 20 & & 0.14 & & \\
\hline 37R-CC, 35-36 & 478.45 & Black sandy claystone & 8 & & 0.15 & & \\
\hline $37 \mathrm{R}-\mathrm{CC}, 39-40$ & 478.49 & Black sandy claystone & 9 & & 0.14 & & \\
\hline
\end{tabular}




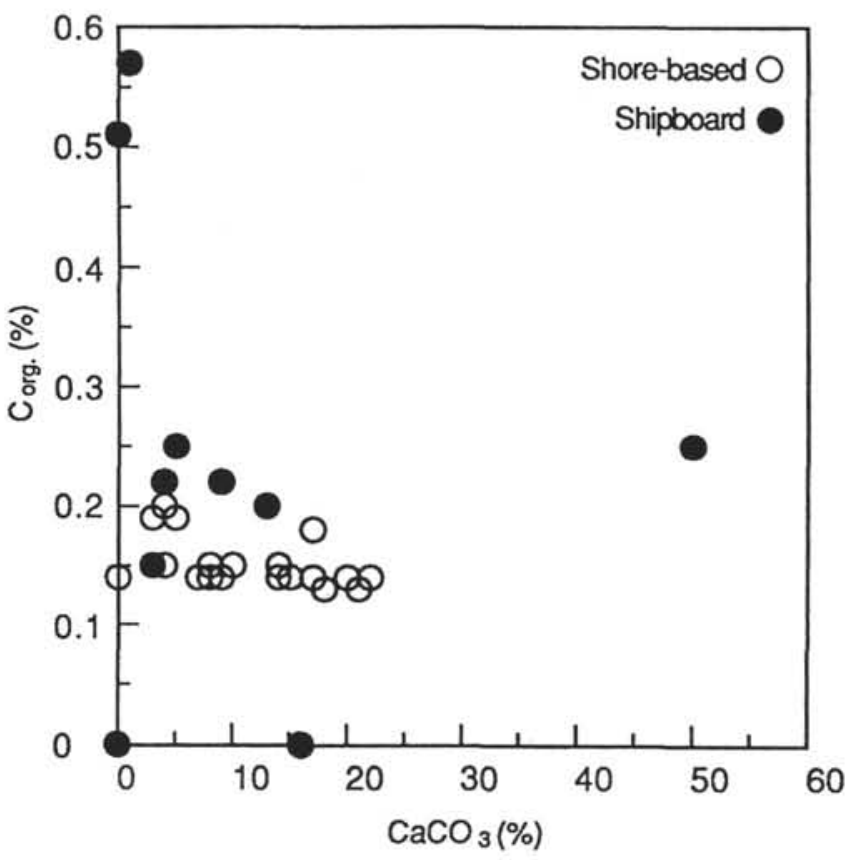

Figure 4. Carbonate content vs. organic contents of sediments around Cenomanian/Turonian boundary at Hole $869 \mathrm{~B}$. There is a strong increase of organic carbon content from shipboard-analyzed samples to shore-based-analyzed samples, probably owing to a systematic error in shipboard analytical procedure.

have been done on this interval, but the grayish-red to yellowishbrown color of the sediments was interpreted as having a low organic carbon content.

\section{Central Pacific Basin}

At Sites 166 and 170 in the Central Pacific Basin, drilling recovered early Hauterivian-to-Turonian calcareous zeolitic mudstone and chert (Winterer, Ewing, et al., 1973). These sediments are devoid of organic matter (Bode, 1973).

\section{Nauru Basin}

Site 462 was drilled during Leg 61 in the Nauru Basin (Larson, Schlanger, et al., 1981), approximately $420 \mathrm{~km}$ southward of Site 869 . Overlying basalt and diabase sills, zeolitic mudstone, and claystone, dominantly red to light brown with grayish-brown to black millimeter-thick laminae occurred in both Holes 462 and 462A. The dark sediments, dated at about the Cenomanian/Turonian boundary, are not rich in organic carbon $(0.03 \%-0.1 \%$ TOC), and they apparently owe their color to enrichment in iron and manganese oxyhydroxides (Simoneit, 1981; White and Bode, 1981).

\section{East Mariana Basin}

Sites 585 and 802 were drilled, respectively, in the eastern and central parts of the Mariana Basin. Forty-six meters of redeposited dark gray claystone of late Cenomanian-to-Santonian age were cored at Site 585 (Moberly, Schlanger, et al., 1986). In both Holes 585 and $585 \mathrm{~A}$, thin beds rich in marine organic matter were cored. In Section 89-585-32-3, a 2-cm-thick band of black, silty, and pyritic claystone was recovered. Shipboard analysis of organic content in samples from this level showed TOC values of $5.6 \%$ and $5.1 \%$, whereas onshore analyses showed an organic carbon amount of $9.9 \%$ (Schlanger et al., 1987). A fairly high hydrogen index of 383 to $423 \mathrm{mg} \mathrm{HC} / \mathrm{g}$ TOC

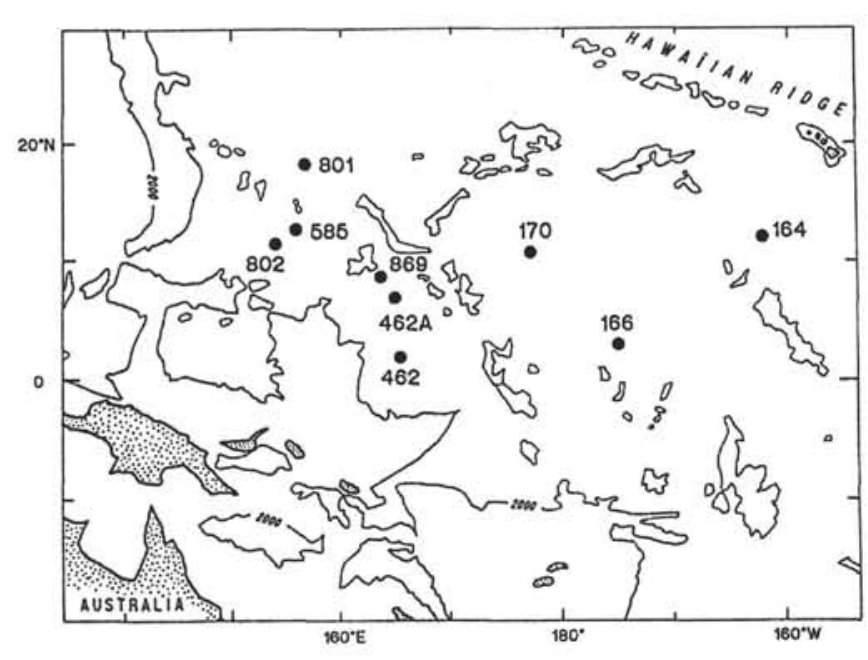

Figure 5. Location map of DSDP and ODP sites with a good record of the Cenomanian to Turonian deep-basin sediments from the central and northwestern Pacific Ocean. Site 164: North of Clarion Fracture Zone, Sites 166 and 170: Central Pacific Basin, Site 462 and 462A: Nauru Basin, Sites 585 and 802 : Mariana Basin, Site 801: Pigaferra Basin, Site 869: Marshall Island Province.

probably reflects an algal origin for the kerogen (Schlanger et al., 1987). The Cenomanian/Turonian boundary was placed within Core 89-585-32, with the latest Cenomanian faunal assemblage occurring in Core 89-585-34. Thus, the organic-carbon-rich horizon is close to the Cenomanian/Turonian boundary. In the core-catcher sample of Core 89-585A-8, a thin lamina of organic- and radiolarian-rich sediments contains $1.45 \%$ or $2.6 \%$ TOC, according to shipboard or shore-based analyses, respectively (Moberly, Schlanger, et al., 1986). The Cenomanian/Turonian boundary was placed $0.5 \mathrm{~m}$ below this level, in Core 89-585A-9 (Moberly, Schlanger, et al., 1986). These organiccarbon-rich layers were described in a turbidite-dominated section and may themselves be interpreted as redeposited (Moberly, Schlanger, et al., 1986; Schlanger et al., 1987).

At Site 802 , located in the central Mariana Basin about $430 \mathrm{~km}$ from Site 585, Cenomanian-to-Coniacian fine-grained radiolarian limestone, nannofossil chalk, and calcareous claystone turbidites were recovered. Thin, discontinuous black layers in Section 129-802A-52R-1 are composed of as much as $50 \%$ iron and manganese oxyhydroxides, and the claystone has a iron and manganese content of about $30 \%$ (Lancelot, Larson, et al., 1990). The organic and inorganic carbon contents were barely investigated during Leg 129, but the reddish-brown to light gray and bluish-gray colors of these sediments suggested low TOC values.

\section{Pigaffeta Basin}

At Site 801 , located in the central part of Pigaffeta Basin, a poorly recovered Cenomanian-to-Coniacian series composed of brown chert, porcellanite, and volcaniclastic sandstone (Lancelot, Larson, et al., 1990) was sampled. To my knowledge, no organic carbon measurements have been done on this interval; however, lithologic descriptions suggest probable organic-carbon-poor levels.

\section{Elsewhere in the Pacific}

Organic-carbon-rich sediments of coeval age have been sampled only from a few DSDP sites, including rises, plateaus, or seamounts: Horizon Guyot, Site 171 (Winterer, Ewing, et al., 1973); Shatsky Rise, Site 305 and Hess Rise, and Site 310 (Larson, Moberly, et al., 1975). All these sites, which were not basinal during Cenomanian to Turonian time, are discussed in detail in Schlanger et al. (1987) and in Arthur et al. (1987). 


\section{CONCLUSIONS}

Basinal deposits recovered at Hole 869B near the Cenomanian/ Turonian boundary exhibit low carbon and carbonate contents. Organic carbon content is everywhere less than $0.2 \%$, whereas the amount of calcium carbonate fluctuates between $0 \%$ and $22 \%$. These values are consistent with most of the basinal sites of the central and northwestern Pacific Ocean, where coeval sediments were investigated at other DSDP and ODP sites. Only a thin, redeposited carbonaceous level from Site 585 represents the deepest manifestation of the Cenomanian-Turonian Oceanic Anoxic Event in the Pacific.

However, a question arises about the effect of the relatively low core recovery in certain Upper Cretaceous series from Pacific deep basins, including Site 869 . If organic matter occurred in very thin laminae, as in the East Mariana Basin, its presence may not have been recognized because of poor recovery. Nevertheless, gamma-ray and other well-logging data (Fig. 3) do not show organic carbon enrichment around the Cenomanian/Turonian boundary at Hole 869B, whereas a pronounced $\delta^{13} \mathrm{C}$ peak is evidence of the Oceanic Anoxic Event (Jenkyns et al., this volume).

Schlanger and Jenkyns (1976) and Schlanger et al. (1987) hypothesized that the deposition of organic-carbon-rich sediments across a range of depth environments during Cenomanian-Turonian time resulted from an expanded oxygen-minimum zone. These authors pointed out that although the Cenomanian-Turonian Oceanic Anoxic Event is characterized by widespread black-shale deposition, an Oceanic Anoxic Event as such does not imply anoxic conditions over the entire world ocean. Several sections drilled in the central and northwestern Pacific indicate that these Cenomanian to Turonian iron- and manganese-rich facies are common in basinal environments. This feature attests to an extremely low rate of deposition, or perhaps to more oxygenated bottom waters. This point is consistent with the oxygen-minimum zone model. That is probably the case in deep basins from central and northwestern Pacific Ocean, where organicrich layers are scarce.

A necessary condition of the oxygen-minimum-zone model proposed to explain the Cenomanian-Turonian Oceanic Anoxic Event within the Pacific is that basinal waters were oxygenated. Owing to the vertically restricted depth of the oxygen-minimum zone, much of the seafloor was in oxygenated waters. Existence of such conditions is now further demonstrated by the deposits of the southern flank of the Pikinni-Wodejebato ridge in the Marshall Islands, as well as for numerous other deep-marine environments from the central and northwestern Pacific Ocean.

\section{ACKNOWLEDGMENT}

The author is grateful to the Ocean Drilling Program for inviting him to participate in Leg 143. I am indebted to the French "Géosciences Marines" program for financial support. The manuscript benefitted from the critical comments of K. Kelts, E.L. Winterer, and an anonymous reviewer, who are acknowledged.

\section{REFERENCES}

Arthur, M.A., Schlanger, S.O., and Jenkyns, H.C., 1987. The CenomanianTuronian oceanic anoxic event: II. Palaeoceanographic controls on organic-matter production and preservation. In Brooks, J., and Fleet, A.J. (Eds.), Marine Petroleum Source Rocks. Geol. Soc. Spec. Publ. London, 26:401-420.

Bode, G.W., 1973. Appendix II. Carbon and carbonate analyses, Leg 17. In Winterer, E.L., Ewing, J.I., et al., Init. Repts. DSDP, 17: Washington (U.S. Govt. Printing Office), 927-930.

Espitalié, J., Deroo, G., and Marquis, F., 1985a. La pyrolyse Rock-Eval et ses applications, partie I. Rev. Inst. Fr. Pet., 40:563-579.

, 1985b. La pyrolyse Rock-Eval et ses applications, partie II. Rev. Inst. Fr. Pet., 40:755-784.

1986. La pyrolyse Rock-Eval et ses applications, partie III. Rev. Inst. Fr. Pet., 41:73-89.

Lancelot, Y., Larson, R.L., et al., 1990. Proc. ODP, Init. Repts., 129: College Station, TX (Ocean Drilling Program).

Larson, R.L., Moberly, R., et al., 1975. Init. Repts. DSDP, 32: Washington (U.S. Govt. Printing Office).

Larson, R.L., Schlanger, S.O., et al., 1981. Init. Repts. DSDP, 61: Washington (U.S. Govt. Printing Office).

Moberly, R., Schlanger, S.O., et al., 1986. Init. Repts. DSDP, 89: Washington (U.S. Govt. Printing Office).

Schlanger, S.O., Arthur, M.A., Jenkyns, H.C., and Scholle, P.A., 1987. The Cenomanian-Turonian oceanic anoxic event, I. Stratigraphy and distribution of organic carbon-rich beds and the marine $\delta^{13} \mathrm{C}$ excursion. In Brooks, J., and Fleet, A.J.(Eds.), Marine Petroleum Source Rocks. Geol. Soc. Spec. Publ. London, 26:371-399.

Schlanger, S.O., and Jenkyns, H.C., 1976. Cretaceous oceanic anoxic events: causes and consequences. Geol. Mijnbouw, 55:179-184.

Shipboard Scientific Party, 1993. Site 869. In Sager, W.W., Winterer, E.L., Firth, J.V., et al., Proc. ODP, Init. Repts., 143: College Station, TX (Ocean Drilling Program), 297-374.

Simoneit, B.R.T., 1981. Lipid geochemistry of sediments from Site 462 in the Nauru Basin. In Larson, R.L., Schlanger, S.O., et al., Init. Repts. DSDP, 61: Washington (U.S. Govt. Printing Office), 627-629.

Tissot, B.P., 1984. Recent advances in petroleum geochemistry applied to hydrocarbon exploration. AAPG Bull., 68:545-563.

White, S., and Bode, G.W., 1981. Appendix II. Grain-size and carbon/carbonate analyses, Leg 61. In Larson, R.L., Schlanger, S.O., et al., Init. Repts. DSDP, 61: Washington (U.S. Govt. Printing Office), 883-885.

Winterer, E.L., Ewing, J.I., et al., 1973. Init. Repts. DSDP, 17: Washington (U.S. Govt. Printing Office). Abbreviations for names of organizations and publications in ODP reference lists follow
the style given in Chemical Abstracts Service Source Index (published by American
Chemical Society).

Date of initial receipt: 24 November 1993

Date of acceptance: 6 July 1994

Ms 143SR-221 